\title{
PENGGUNAAN BAHASA INDONESIA PADA DISKUSI SISWA SMANEGERI 4 SURAKARTA : KAJIAN DENGAN PRINSIP KERJA SAMA GRICE DAN RELEVANSINYA SEBAGAI BAHAN AJAR KETERAMPILAN BERBICARA
}

\author{
Sarah Apriani B. A. M., Budhi Setiawan, Kundharu Saddhono \\ Universitas Sebelas Maret \\ Surel: sarahaprianibam@student.uns.ac.id
}

\begin{abstract}
This study aims to (1) describe and explain the realization of the following Grice's cooperative principles; (2) describe and explain the realization of the violatting Grice's cooperative principles; and (3) explains the relevance of Grice's principles of cooperation as teaching materials for high school speaking skills. This research is a qualitative descriptive research. Sources of data was a transcripted document form. The technique for taking the subject was done by purposive sampling. Data analysis in this study was using the flow model. The results of the study are as follows. First, the maxim of 'quantity' of the Grice's cooperative principle of was the most followed as many as 35 data (59,3\%). Second, the maxim of 'quantity' was also the most violated as many as 33 data (48,5\%). Third, Grice's coopertive principles can be used as teaching materials of speaking skills in high school because (1) it provides guidance to students; (2) it provides guidance for teachers in giving score; and (3) it improves effectiveness in the learning process of speaking skills, especially in discussion activities.
\end{abstract}

Keywords: compliance, violation, principles of cooperation, discussion, teaching materials

\begin{abstract}
Abstrak: Penelitian ini bertujuan untuk (1) mendeskripsikan dan menjelaskan realisasi pematuhan prinsip kerja sama; (2) mendeskripsikan dan menjelaskan realisasi pelanggaran prinsip kerja sama; dan (3) menjelaskan relevansi prinsip kerja sama sebagai bahan ajar keterampilan berbicara di SMA. Penelitian ini merupakan penelitian deskriptif kualitatif. Sumber data berupa dokumen transkrip. Teknik pengambilan subjek dilakukan dengan sampel bertujuan. Uji validitas data yang digunakan adalah teknik triangulasi teori dan sumber data. Analisis data menggunakan model mengalir. Hasil penelitian ini sebagai berikut. Pertama, pematuhan prinsip kerja sama Grice paling dominan muncul pada maksim kuantitas yaitu sebanyak 35 data $(59,3 \%)$. Kedua, pelanggaran prinsip kerja sama Grice paling dominan juga muncul pada maksim kuantitas yaitu sebanyak 33 data (48,5\%). Ketiga, prinsip kerja sama Grice baik dapat dijadikan sebagai rujukan bahan ajar keterampilan berbicara di SMA karena (1) memberikan rambu-rambu kepada siswa; (2) memberikan pedoman penilaian bagi guru; dan (3) meningkatkan efektifitas proses pembelajaran keterampilan berbicara, khususnya pada kegiatan diskusi.
\end{abstract}

Kata kunci: pematuhan, pelanggaran, prinsip kerja sama, diskusi, bahan ajar. 


\section{PENDAHULUAN}

Bahasa merupakan sebuah sistem berupa lambang bunyi yang digunakan oleh anggota kelompok masyarakat untuk berinteraksi dan menyampaikan maksud. Hal ini berguna untuk mencapai tujuan yang diinginkan selama proses berkomunikasi. Bahasa sebagai alat komunikasi memiliki peran sebagai perantara informasi dalam proses berkomunikasi. Hal tersebut sesuai dengan pernyataan Kentjono (Wijana \& Rohmadi, 2011:188) bahwa ada tiga fungsi utama bahasa, yaitu sebagai alat kerja sama, berkomunikasi, dan mengidentifikasi diri. Berkaitan dengan fungsi bahasa tersebut maka bahasa sangat dibutuhkan dalam pembelajaran di sekolah, khususnya pembelajaran bahasa Indonesia.

Pembelajaran bahasa Indonesia dilakukan supaya kemampuan siswa dalam berkomunikasi menggunakan bahasa Indonesia dengan baik dan benar secara lisan maupun tulisan meningkat. Dalam pembelajaran bahasa Indonesia, terdapat empat keterampilan berbahasa yaitu keterampilan menyimak, membaca, berbicara, dan menulis. Keempat keterampilan berbahasa ini saling berkaitan dan tidak dapat dipisahkan antara satu dengan yang lainnya.

Keterampilan berbicara merupakan kemampuan mengucapkan bunyibunyi artikulasi atau mengucapkan kata-kata untuk mengapresiasi, menyatakan, menyampaikan pikiran, gagasan, dan perasaan. Berbicara dapat ditinjau sebagai seni dan sebagai ilmu. Berbicara sebagai seni menekankan penerapannya sebagai alat komunikasi dalam masyarakat, dan yang menjadi perhatiannya antara lain (1) berbicara di muka umum, (2) diskusi kelompok, dan (3) debat (Arsjad \& Mukti dalam Saddhono \& Slamet, 2014:59\&90). Keterampilan berbicara dalam pembelajaran bahasa Indonesia dapat dilihat misalnya dari diadakannya diskusi kelompok siswa. Siswa dapat melatih komunikasi yang efektif dan efisien sesuai dengan etika yang berlaku melalui kegiatan diskusi.

Kegiatan diskusi dalam pembelajaran bahasa Indonesia menuntut siswa memiliki keterampilan berbicara yang baik dalam menyampaikan pertanyaan, pernyataan, kritikan, ataupun sanggahannya. Siswa sebagai penutur dan siswa lain sebagai mitra tutur haruslah saling bekerja sama dalam proses komunikasi pada kegiatan diskusi. Hal ini dilakukan supaya tidak terjadi kesalahpahaman dalam 
memberikan dan menerima informasi yang ada. Akan tetapi, memang tidak selamanya peristiwa komunikasi dalam kegiatan diskusi dapat terlaksana dengan baik dan bermakna tanpa adanya suatu hambatan.

Hambatan dalam proses berkomunikasi dalam kegiatan diskusi dapat terjadi karena adanya dua faktor, yaitu faktor eksternal dan faktor internal. Faktor eksternal adalah faktor yang berasal dari luar penutur dan mitra tutur ketika proses komunikasi dalam diskusi terjadi, seperti alat, tempat, dan waktu pelaksanaan diskusi yang kurang mendukung. Lain halnya dengan faktor internal yang dimaksudkan adalah apabila penutur dan mitra tutur tidak memahami topik yang sedang dibicarakan atau salah satu penuturnya tidak mengetahui konteks tuturan dalam kegiatan diskusi. Oleh karena itu, faktor situasi dan konteks tuturan juga merupakan faktor penting dalam penggunaan bahasa ketika proses komunikasi, terutama dalam kegiatan diskusi.

Jika salah satu penutur tidak memahami situasi dan konteks tuturan maka dapat dipastikan proses komunikasi dalam diskusi tidak akan berjalan lancar. Bahkan bisa saja informasi yang disampaikan tidak dapat diterima dengan baik oleh mitra tuturnya. Dengan kata lain, agar proses komunikasi dapat berjalan baik dan lancar, mereka haruslah dapat saling bekerja sama melalui Prinsip kerja sama Grice.

Prinsip kerja sama Grice menghendaki penggunaan bahasa yang efektif dan efisien seperti yang tampak pada maksim-maksim dalam prinsip kerja sama tersebut. Jadi dengan adanya Prinsip kerja sama Grice dalam komunikasi, penutur dan mitra tutur akan lebih mudah menjelaskan hubungan maksud dengan ujaran yang disampaikannya (Sari, 2013). Prinsip kerja sama Grice terdiri atas empat macam maksim percakapan (conversational maxim), yaitu maksim kuantitas (maxim of quantity), maksim kualitas (maxim of quality), maksim relevansi (maxim of relevance), dan maksim cara (maxim of manner).

The maxim of quantity (Rahardi, 2005:52): a) make your contribution as informative as required; b) do not make your contribution more informative than required. Kemudian Leech (2011:11-12) menjelaskan bahwa a) sumbangan informasi Anda harus seinformatif yang dibutuhkan; b) sumbangan informasi 
Anda jangan melebihi yang dibutuhkan. Maksim kuantitas dalam penuturan ini menyangkut jumlah kontribusi terhadap koherensi percakapan. Maksim ini mengarahkan kontribusi yang cukup memadai dari seorang penutur dan di dalam penutur suatu penutur suatu percakapan. Maksud submaksim (a) dan (b) adalah bahwa sumbangan atau kontribusi tiap-tiap penutur hendaknya tepat sesuai dengaan yang diperlukan. Jika kontribusi yang diperlukan sedikit, penutur pun hanya memberikan kontribusi sedikit pula, demikian sebaliknya.

The maxim of quality (Rahardi, 2005:52): a) do not say what you believe to be false; b) Do not say that for which you lack adequate evidence. Kemudian Leech (2011:11-12) menjelaskan bahwa a) jangan mengatakan suatu yang Anda yakini bahwa itu tidak benar; b) jangan mengatakan suatu yang bukti kebenarannya kurang meyakinkan. Maksim kualitas berisi nasihat untuk memberikan kontribusi yang benar dengan kontribusi yang benar dengan buktibukti tertentu. Kedua submaksim mengharuskan peserta percakapan mengatakan hal yang benar. Atas dasar dua submaksim itu pula hendaknya penutur mendasarkan tuturannya pada bukti-bukti yang memadai.

The maxim of relevance: (Rahardi, 2005:52): Make your contribution relevant. Kemudian Leech (2011:11-12) menjelaskan bahwa usahakan agar perkataan Anda ada relevansinya. Maksim hubungan menyarankan penutur untuk mengatakan apa-apa yang relevan. Mengikuti nasihat itu sama dengan mengikuti prinsip kerja sama yang akan menghasilkan tuturan yang bersifat kooperatif. Sebaliknya, tidak mengikuti atau menyimpang dari nasihat itu sama dengan tidak menjalankan prinsip kerja sama yang akan menghasilkan tuturan yang tidak kooperatif. Kontribusi penutur yang relevan dengan masalah yang dibicarakan merupakan keharusan bagi penutur dalam mengikuti maksim relevansi ini.

The maxim of manner (Rahardi, 2005:52): Be perspicuous and specifically: a) avoid obscurity; b) avoid ambiguity; c) be brief; d) be orderly. Kemudian Leech (2011:11-12) menjelaskan bahwa usahakan agar perkataan Anda mudah dimengerti, yaitu: a) hindarilah pernyataan-pernyataan yang samar; b) hindarilah ketaksaan; c) usahakan agar ringkas (hindarilah pernyataan-pernyataan yang panjang lebar dan bertele-tele); dan d) usahakan agar Anda berbicara teratur. 
Berdasarkan hasil observasi yang dilakukan oleh peneliti di beberapa kelas XI SMA Negeri 4 Surakarta menunjukkan bahwa adanya pematuhan dan pelanggaran prinsip kerja sama Grice dalam kegiatan diskusi siswa tersebut. Kegiatan diskusi siswa kelas XI SMA Negeri 4 Surakarta dalam pembelajaran bahasa Indonesia cukup baik. Memang tidak seluruh siswa berperan aktif untuk bertanya maupun menjawab, sehingga hanya penggunaan bahasa Indonesia pada beberapa siswa saja yang berhasil diobservasi oleh peneliti. Peristiwa ketika siswa aktif berbicara dengan penguasaan kosakata, pemahaman, dan penyampaian yang baik akan mengakibatkan adanya pematuhan prinsip kerja sama Grice. Lain halnya dengan pelanggaran prinsip kerja sama Grice terjadi ketika siswa terbiasa berbicara panjang lebar dan menggunakan kalimat yang mubazir, adanya kebiasaan bertanya atau memberi jawaban yang keluar dari topik diskusi (tidak sesuai topik diskusi), lalu menimbulkan kegaduhan dalam kelas, seperti tertawa ataupun siswa lain mengomentari siswa tersebut. Walaupun demikian, kegiatan diskusi siswa di dalam kelas pun masih dapat bejalan dengan lancar.

Prinsip kerja sama Grice akan memperbaiki proses diskusi jika diterapkan dengan tepat. Hal ini dapat dibuktikan melalui penelitian yang dilakukan oleh Handoko (2010) yang menyatakan bahwa terdapat peningkatan proses pembelajaran diskusi dan kemampuan berdiskusi siswa kelas VIII D SMP Negeri 10 Surakarta melalui penerapan prinsip kerja sama Grice. Peningkatan proses diskusi terlihat dari meningkatnya kualitas aktivitas siswa selama pembelajaran berdiskusi, penyampaian sesuatu dengan argument yang benar dan jelas, penyampaian sesuatu secara efektif, penyampaian sesuatu berhubungan dengan topik, penyampaian sesuatu menggunakan etika yang benar, dan kemampuan mempertahankan pendapat dengan argument yang dapat diterima. Peningkatan kemampuan berdiskusi dapat dilihat dari nilai berdiskusi siswa yang diambil oleh guru pada saat pembelajaran yang selalu meningkat pada setiap siklusnya. Hal ini membuktikan bahwa dengan penerapan prinsip kerja sama Grice mampu meningkatkan kualitas proses pembelajaran dan sekaligus mampu meningkatkan kemampuan berdiskusi siswa. 


\section{METODE PENELITIAN}

Penelitian ini menggunakan metode kualitatif deskriptif. Menurut Moleong (2007:6), penelitian kualitatif merupakan penelitian yang bermaksud untuk memahami fenomena tentang yang dialami subjek penelitian secara menyeluruh dengan cara deskriptif dalam bentuk kata-kata dan bahasa, pada konteks khusus yang alamiah dengan memanfaatkan berbagai metode alamiah. Istilah deskriptif maksudnya adalah data yang dikumpulkan berupa kata-kata bukan angka (Moleong, 2007:11). Dalam penelitian ini, peneliti mencatat dengan teliti dan cermat data-data penggunaan bahasa yang terdapat dalam diskusi siswa kelas XI IPA 1 ketika pembelajaran bahasa Indonesia berlangsung. Dengan demikian, hasil analisisnya akan berbentuk deskripsi. Pendekatan dalam penelitian ini merupakan pendekatan pragmatik, yaitu pendekatan yang mendasarkan diri pada reaksi atau tanggapan mitra tutur atau lawan tutur (Subroto, 2007:65). Pendekatan pragmatik digunakan untuk menjawab permasalahan penelitian.

Sumber data adalah bagian dalam teknik penelitian kualitatif, yang menjadi tempat atau sumber pemerolehan data (subjek penelitian) yang bersifat natural, alami, tanpa pengaruh dari peneliti. Mahsun (2011:28) berpendapat bahwa sumber data terdiri atas populasi, sampel, dan informan. Adapun sumber data dalam penelitian ini adalah dokumen yang berupa transkrip hasil rekaman penggunaan bahasa Indonesia pada diskusi siswa kelas XI IPA 1 SMAN 4 Surakarta. Sumber data diambil ketika berlangsungnya proses tanya jawab dalam diskusi siswa pada pembelajaran bahasa Indonesia.

Teknik pengambilan subjek penelitian ini dilakukan dengan sampel bertujuan (purposive sampling), artinya peneliti dengan sengaja mencari sampel sampai dengan keterangan atau karakteristik yang diharapkan dan disesuaikan dengan tujuan penelitian. Menurut Sugiyono (2015:300) purposive sampling adalah teknik pengambilan sampel sumber data dengan pertimbangan tertentu, seperti orang yang dianggap tahu tentang apa yang diharapkan. Dalam penelitian ini, peneliti mempertimbangkan sampel yang dipilih akan mewakili penggunaan bahasa yang dapat ditinjau dari prinsip kerja sama Grice, baik itu penggunaan 
bahasa yang memenuhi ataupun yang melanggar maksim-maksim dalam prinsip kerja sama Grice.

Penulis menggunakan metode simak sebagai metode penyediaan data dalam penelitian ini. Metode ini memiliki teknik dasar yang berwujud teknik sadap. Teknik sadap untuk menyadap penggunaan bahasa dalam diskusi yang dilakukan oleh siswa XI IPA 1 SMA Negeri 4 Surakarta pada pembelajaran bahasa Indonesia. Diskusi tersebut mengacu pada Kompetensi Dasar (KD) 3.10 dan 4.10. Dalam praktik selanjutnya, teknik sadap ini diikuti dengan teknik lanjutan yang berupa teknik simak libat cakap, teknik rekam, dan teknik catat.

Teknik uji validitas data yang digunakan adalah teknik triangulasi teori dan triangulasi sumber data berupa informan. Triangulasi teori terfokus berdasarkan maksim-maksim pada prinsip kerja sama, yaitu yang terdiri dari maksim kuantitas, maksim kualitas, maksim relevansi, dan maksim pelaksanaan/cara. tanggapan mengenai relevansi penelitian ini sebagai bahan ajar keterampilan berbicara. Adapun informan yang akan peneliti wawancarai adalah satu guru pengampu mata pelajaran Bahasa Indonesia dan salah satu pengurus MGMP mata pelajaran Bahasa Indonesia.

\section{HASIL PENELITIAN DAN PEMBAHASAN}

Realisasi Penggunaan Bahasa Indonesia pada Diskusi Siswa Kelas XI yang Mematuhi Prinsip Kerja Sama

Realisasi penggunaan bahasa Indonesia yang mematuhi prinsip kerja sama Grice pada pembelajaran diskusi siswa kelas XI IPA 1 SMAN 4 Surakarta terjadi secara komprehensif ketika proses tanya jawab berlangsung. Berikut ini akan dipaparkan tabel data pematuhan prinsip kerja sama Grice dalam diskusi siswa kelas XI IPA 1 SMAN 4 Surakarta.

\begin{tabular}{ccc}
\hline $\begin{array}{c}\text { Maksim Prinsip Kerja } \\
\text { Sama Grice }\end{array}$ & $\begin{array}{c}\text { Jumlah } \\
\text { (data) }\end{array}$ & $(\%)$ \\
\hline Maksim Kuantitas & 35 & 59,3 \\
\hline
\end{tabular}




\begin{tabular}{|c|c|c|}
\hline Maksim Kualitas & 9 & 15,3 \\
\hline Maksim Relevansi & 7 & 11,9 \\
\hline Maksim Cara & 8 & 13,6 \\
\hline TOTAL & 59 & 100 \\
\hline
\end{tabular}

Tabel 1. Data Pematuhan Prinsip Kerja Sama Grice

Tabel di atas menunjukkan bahwa pematuhan maksim kuantitas memiliki jumlah data paling banyak, yakni 35 data atau mencapai 59,3\% dari keseluruhan data yang ditemukan. Pematuhan maksim kualitas menempati posisi kedua dengan jumlah data 9 atau mencapai 15,3\%. Kemudian, pematuhan maksim kualitas menempati posisi ketiga dengan jumlah data $8(13,6 \%)$ dan pematuhan maksim relevansi menempati posisi akhir dengan jumlah data $7(11,9 \%)$.

Pematuhan maksim prinsip kerja sama Grice paling dominan muncul pada maksim kuantitas. Data hasil penelitian ini menunjukkan bahwa pematuhan maksim kuantitas terjadi pada jawaban yang disampaikan siswa (mitra tutur) untuk menjawab pertanyaan atau tanggapan dari siswa lain (penutur). Ada jawaban yang tidak terlalu singkat, tetapi isi jawabannya juga tidak melebihi dari informasi yang dibutuhkan oleh mitra tutur. Selain itu, juga ada jawaban yang sangat singkat, tetapi jawaban tersebut juga sangat tepat dan memadai sesuai dengan kontribusi informasi yang diminta oleh siswa lainnya (penutur).

Jawaban informatif walaupun sangat singkat atau tidak terlalu singkat tersebut tetap dapat dipahami oleh siswa lainnya yang terdapat dalam kegiatan diskusi siswa kelas XI IPA 1 SMAN 4 Surakarta. Hal ini menunjukkan adanya pemahaman yang baik mengenai topik diskusi yang sedang dibahas. Kemampuan siswa dalam memberi pertanyaan, menyampaikan jawaban atau tanggapan pun menunjukkan bahwa siswa (penutur) mampu berbicara dengan baik, lugas, dan dapat dimengerti oleh siswa lainnya (mitra tutur).

Hal ini sejalan dengan hasil penelitian yang dilakukan oleh Sari (2013) yang menyatakan bahwa dalam percakapan siswa terhadap guru, tindak tutur siswa yang mematuhi maksim kuantitas digunakan siswa untuk menanggapi tindak tutur guru dengan memberikan informasi yang diperlukan saja. Tindak 
tutur tersebut cenderung menunjukkan terciptanya hubungan harmonis dan pencapaian pemahaman bersama. Hasil Penelitian yang dilakukan oleh Devi dan Qomaruddin (2017) juga berpendapat bahwa pematuhan prinsip kerja sama pada maksim kuantitas ini menyebabkan percakapan antara keduanya lebih efektif dan jelas sehingga mudah dipahami. Hal ini menunjukkan bahwa terdapat pemahaman yang sama mengenai topik yang sedang dibahas.

Pematuhan maksim kualitas pada diskusi siswa kelas XI IPA 1 SMAN 4 Surakarta berdasarkan data hasil penelitian yang ada terjadi ketika siswa (mitra tutur) menuturkan informasi yang sudah diyakininya benar adanya. Kebenaran informasi yang disampaikan siswa ketika proses tanya jawab diskusi berlangsung sebenarnya merupakan keharusan bagi siswa tersebut untuk membiasakan diri berbicara jujur dan benar. Hal ini sejalan dengan hasil penelitian yang dilakukan oleh Payuyasa, dkk (2014) yang menyatakan bahwa dalam pembelajaran tuntutan siswa untuk menjawab benar adalah kewajiban yang harus ditunaikan siswa. Dengan demikian, ketika siswa berbicara jujur dan menyampaikan informasi yang benar maka siswa tersebut mematuhi prinsip kerja sama Grice pada maksim kualitas.

Pematuhan maksim relevansi terjadi ketika tuturan yang disampaikan oleh siswa kelas XI IPA 1 SMAN 4 Surakarta selama diskusi berlangsung relevan dengan topik diskusi. Sebenarnya secara keseluruhan, hampir semua tuturan siswa kelas XI IPA 1 SMAN 4 Surakarta selalu berkaitan dengan topik yang sedang dibahas dalam diskusi. Hal ini dikarenakan topik diskusi sudah dibatasi, yaitu Upaya Menuju Generasi Tanpa Merokok Sebuah Pencegahan dan Penanggulangan.

Pematuhan maksim cara dari data hasil penelitian ini terjadi pada tuturan siswa yang jelas (tidak acak), dapat dimengerti, dan langsung menuju ke inti informasi yang ingin disampaikan. Pematuhan maksim cara juga berhubungan dengan sikap siswa yang menyampaikan tuturannya dengan tenang dan teratur. Sikap siswa yang demikian memang perlu terus dilatih supaya ketika siswa (penutur) berbicara dapat memunculkan kesepahaman yang sama. Kesepahaman 
yang sama ini berarti tidak menyampaikan kalimat yang bermakna ganda sehingga membuat siswa lainnya (mitra tutur) menjadi kebingungan.

Hal ini sejalan dengan dengan hasil penelitian yang dilakukan oleh Sari (2013) yang berpendapat bahwa pematuhan maksim cara terjadi ketika tindak tutur yang disampaikan siswa dari hal awal yang harus dilakukan sampai dengan hal terakhir. Tindak tutur tersebut dinyatakan dengan tuturan yang runtut, tidak acak-acakan. Tindak tutur itu sangat jelas mengacu pada hal-hal inti dan tidak banyak disertai langkah-langkah tambahan. Dengan demikian akan tercapai kesepakatan bersama yang selanjutnya mencapai pemahaman bersama. Lain halnya dengan penelitian yang dilakukan oleh Devi dan Qomaruddin (2017) yang menyatakan bahwa pematuhan prinsip kerja sama pada maksim cara ini diharapkan percakapan antara keduanya dapat menghindari ambiguitas. Hal tersebut dilakukan agar komunikasi antara keduanya berjalan dengan lancar dan tepat.

Realisasi Penggunaan Bahasa Indonesia pada Diskusi Siswa Kelas XI yang Melanggar Prinsip Kerja Sama Grice

Realisasi penggunaan bahasa Indonesia yang melanggar prinsip kerja sama Grice pada kegiatan diskusi siswa kelas XI IPA 1 SMAN 4 Surakarta terjadi karena dipengaruhi oleh faktor internal, seperti (1) tingkat kemampuan berbicara siswa yang berbeda, (2) keberanian siswa dalam menyampaikan pendapat, dan (3) tingkat pemahaman siswa terhadap topik diskusi. Selain karena faktor internal, ada faktor eksternal yang juga mempengaruhi pelanggaran prinsip kerja sama dalam diskusi siswa kelas XI IPA 1 SMAN 4 Surakarta. Faktor eksternal tersebut adalah jadwal pelajaran bahasa Indonesia yang terdapat di akhir jam belajar di kelas sehingga fokus siswa dalam berdiskusi menurun. Suasana kelas juga menjadi kurang kondusif karena beberapa siswa tidak memperhatikan bahkan ada juga yang bercanda dengan temannya.

Seperti telah dipaparkan pada bagian Deskripsi Hasil Penelitian, pelanggaran prinsip kerja sama Grice terjadi dalam diskusi siswa kelas XI IPA 1 
SMAN 4 Surakarta. Pelanggaran-pelanggaran tersebut terjadi pada semua maksim dalam prinsip kerja sama.

\begin{tabular}{|c|c|c|}
\hline Maksim Prinsip Kerja Sama Grice & Jumlah & $(\%)$ \\
\hline Maksim Kuantitas & 33 & 48.5 \\
\hline Maksim Kualitas & 4 & 5.9 \\
\hline Maksim Relevansi & 6 & 8.8 \\
\hline Maksim Cara & 25 & 36.8 \\
\hline TOTAL & 68 & 100 \\
\hline
\end{tabular}

Tabel 2. Data Pelanggaran Prinsip Kerja Sama Grice

Tabel di atas memaparkan tentang jumlah pelanggaran prinsip kerja sama Grice dalam diskusi siswa kelas XI IPA 1 SMAN 4 Surakarta. Dapat dilihat dalam tabel bahwa pelanggaran paling banyak terjadi pada maksim kuantitas, yakni 33 data atau mencapai $48,5 \%$ dari keseluruhan data yang ditemukan. Pelanggaran maksim cara menempati posisi kedua dengan jumlah data 25 atau mencapai 36,8\%. Kemudian, pelanggaran maksim relevansi menempati posisi ketiga dengan jumlah data $6(8,8 \%)$ dan pematuhan maksim kualitas menempati posisi akhir dengan jumlah data $4(5,9 \%)$.

Pelanggaran maksim prinsip kerja sama Grice yang paling dominan muncul pada maksim kuantitas. Berdasarkan data hasil penelitian yang ada, beberapa tuturan siswa yang melanggar maksim kuantitas merupakan tuturan yang tidak dapat menjawab kebutuhan informasi yang dibutuhkan. Pelanggaran maksim kuantitas juga terjadi pada siswa yang berbicara panjang dengan maksud ingin memberikan informasi yang sangat jelas, lengkap. Kemudian tuturan tersebut diulang dengan tujuan penegasan supaya dapat dipahami lebih baik atau supaya informasi yang disampaikan lebih meyakinkan.

Sebagai contoh pada Data 70, Danik menyebutkan perbandingan kandungan nikotin pada rokok elektik dan kretek juga menjelaskan maksud dari perbandingan tersebut padahal informasi itu tidak diminta. Dengan demikian Danik dengan sengaja melanggar maksim kuantitas agar tuturannya. Hal ini sejalan dengan hasil penelitian yang dilakukan oleh Devi dan Qomaruddin (2017) 
yang menyatakan bahwa pelanggaran prinsip kerja sama pada maksim kuantitas dengan tujuan yaitu penjual meyakinkan pembeli agar tidak ragu dengan kualitas barang yang akan dibelinya. Dengan kata lain, ada kesengajaan untuk melanggar maksim kuantitas dengan harapan supaya informasi yang disampaikan benarbenar diterima oleh mitra tutur. Akan tetapi, tuturan-tuturan yang disampaikan dengan tujuan penegasan ulang atau untuk lebih meyakinkan mitra tutur tetap saja melanggar maksim kuantitas.

Pelanggaran maksim kuantitas terjadi pada siswa yang seringkali terlalu bersemangat dan percaya diri dalam menyampaikan tuturannya, sehingga tidak terasa bahwa hal yang disampaikannya sudah melebihi dari hal yang dibutuhkan mitra tutur. Hal ini sejalan dengan contoh pelanggaran maksim yang ditemukan dalam penelitian yang dilakukan oleh Fajrin, dkk (2016). Penelitian tersebut menyatakan bahwa pelanggaran maksim kuantitas terjadi pada setiap peserta pertuturan yang berlebihan dalam memberikan jawaban atau komentar. Hal ini sesuai dengan temuan peneliti pada data 66 dimana tuturan Danik sebagai mitra tutur melebihi batas informasi yang seharusnya dibutuhkan Natasha. Kontribusi informasi yang dibutuhkan Natasha adalah jawaban dari pertanyaan "apa", tetapi Danik memberikan jawaban dari pertanyaan "mengapa".

Pelanggaran maksim kualitas adalah kondisi dimana penutur memberikan kontribusi yang tidak benar dan tanpa adanya bukti-bukti tertentu. Realisasi pelanggaran maksim kualitas ini terjadi ketika siswa ragu-ragu terhadap hal yang disampaikannya dan atau siswa tidak mendukung hal yang disampaikannya dengan bukti-bukti yang kuat. Pelanggaran maksim ini paling sedikit terjadi karena setiap jawaban yang diberikan oleh siswa berdasarkan pada buku non fiksi yang dijadikan topik diskusi. Siswa juga berusaha browsing di internet untuk mendapatkan bukti atau dukungan untuk jawaban yang mereka berikan.

Pelanggaran maksim kualitas juga muncul ketika tuturan yang disampaikan siswa tersebut memiliki maksud bercanda. Padahal siswa tersebut tahu bahwa informasi yang disampaikannya adalah informasi yang tidak benar. Hal ini sejalan dengan penelitian yang dilakukan oleh Ristiawan (2017) yang berjudul Prinsip kerja sama dalam Berinteraksi di Lingkungan SMPN 11 Kota 
Jambi yang menyatakan bahwa prinsip kerja sama menurut Grice harus dipatuhi demi mencapai tujuan suatu tuturan. Salah satu tujuan tuturannya terdapat pada pelanggaran maksim kualitas, yaitu tujuan humor ketika ada siswa 1 yang bertanya berat badan temannya yang kurus. Namun siswa 2 menjawab dengan bercanda dan tidak sesuai dengan informasi yang sebenarnya.

Pelanggaran maksim relevansi adalah kondisi dimana penutur tidak memberikan kontribusi yang relevan dengan topik atau masalah yang dibicarakan. Realisasi pelanggaran maksim relevansi memang sedikit terjadi karena siswa sudah memahami batasan topik diskusi atau permasalahan yang dibicarakan. Tuturan siswa yang tidak relevan terkadang ada yang secara tidak sengaja tersampaikan (siswa tidak sadar bahwa hal yang disampaikannya tidak relevan dengan topik diskusi atau masalah yang dibicarakan). Contoh seperti ini terjadi pada Data 98. Dalam Data 98, Theo melanggar maksim relevansi karena dia memberikan jawaban secara spontan. Theo tidak sempat untuk memilih dan menyusun kata-katanya dengan baik sehingga jawaban yang diberikan tidak relevan.

Hal ini sejalan dengan hasil penelitian yang dilakukan oleh Payuyasa, dkk (2014) yang menyatakan bahwa siswa yang kurang fokus juga bisa memberikan jawaban yang kurang relevan. Persamaan hasil penelitian yang dimaksudkan dalam hasil penelitian tersebut yaitu pelanggaran maksim relevansi terjadi karena adanya siswa yang kurang fokus sama dengan hasil penelitian yang didapat oleh peneliti yaitu adanya siswa yang tidak sadar terhadap informasi yang disampaikannya.

Pelanggaran prinsip kerja sama Grice juga ditemukan dalam penelitian yang dilakukan oleh Devi dan Qomaruddin (2017) yang menyatakan bahwa alasan terjadinya pelanggaran prinsip kerja sama dalam bahasa transaksi jual beli online di tokopedia.com disebabkan oleh motif-motif tertentu dari penutur maupun mitra tutur. Perbedaan motif penutur maupun mitra tutur menyebabkan pelanggaran pada keempat maksim prinsip kerja sama Grice. Salah satu contohnya adalah pelanggaran pada maksim relevansi yang menyebabkan komunikasi menjadi kurang lancar. Hal ini sesuai dengan temuan peneliti pada 
data 98 dimana Theo sebagai mitra tutur menjawab dengan hal yang tidak relevan. Ketidarelevanan jawaban Theo disebabkan adanya motif humor yang secara tidak sadar terlontar dan berdampak pada suasana diskusi sehingga menjadi kurang kondusif.

Pelanggaran maksim cara adalah kondisi dimana penutur memberikan kontribusi yang tidak jelas dan sulit dimengerti, sehingga tuturan yang didengar tidak dapat dipahami dengan baik. Realisasi pelanggaran maksim cara terjadi ketika tuturan siswa tidak jelas, kata yang disampaikan memiliki kedwimaknaan, panjang, dan berbelit-belit, bahkan ketika pelafalannya tidak teratur. Hal ini sejalan dengan pendapat Rahardi (2005: 57), maksim cara mengharuskan peserta pertuturan bertutur secara langsung, jelas, dan tidak kabur. Maksim ini merupakan maksim yang kedua paling banyak dilanggar oleh siswa selama berdiskusi.

Relevansi Prinsip Kerja Sama Grice Baik yang Mematuhi Maupun Melanggar dalam Hasil Penelitian ini Sebagai Bahan Ajar Keterampilan Berbicara di SMA

Keterampilan berbicara siswa SMA kelas XI dapat diukur salah satunya melalui pembelajaran bahasa Indonesia di sekolah pada kegiatan diskusi di kelas. Diskusi mampu menunjukkan keterampilan berbicara yang dimiliki setiap siswa melalui meminta atau memberikan informasi. Materka (1991: 60) berpendapat bahwa untuk melihat orang mampu atau tidak mampu dalam berdiskusi, maka ada beberapa kemampuan yang harus dimiliki antara lain (1) kemampuan memberikan tanggapan, kemampuan memberikan pertanyaan, (3) kemampuan memberikan jawaban, dan (4) kemampuan memberikan pendapat atau saran.

Prinsip kerja sama Grice membahas tentang empat aspek yang penting dalam berinteraksi dengan orang lain maupun suatu kelompok. Keempat prinsip tersebut adalah kuantitas (banyak atau sedikit), kualitas (kebenaran), relevansi (hubungan), dan cara (pelaksanaan). Dalam kegiatan diskusi, baik itu diskusi formal maupun informal, prinsip-prinsip tersebut dibutuhkan untuk memperbaiki kualitas proses dan hasil diskusi. Prinsip kerja sama Grice akan memperbaiki proses diskusi jika diterapkan dengan tepat. 
Hal ini dapat dibuktikan melalui penelitian yang dilakukan oleh Handoko (2010) yang menyatakan bahwa terdapat peningkatan proses pembelajaran diskusi dan kemampuan berdiskusi siswa kelas VIII D SMP Negeri 10 Surakarta melalui penerapan Prinsip kerja sama Grice. Peningkatan proses diskusi terlihat dari meningkatnya kualitas aktivitas siswa selama pembelajaran berdiskusi, penyampaian sesuatu dengan argumen yang benar dan jelas, penyampaian sesuatu secara efektif, penyampaian sesuatu berhubungan dengan topik, penyampaian sesuatu menggunakan etika yang benar, dan kemampuan mempertahankan pendapat dengan argumen yang dapat diterima. Peningkatan kemampuan berdiskusi dapat dilihat dari nilai berdiskusi siswa yang diambil oleh guru pada saat pembelajaran yang selalu meningkat pada setiap siklusnya. Hal ini membuktikan bahwa penerapan prinsip kerja sama Grice mampu meningkatkan kualitas proses pembelajaran dan sekaligus mampu meningkatkan keterampilan berbicara siswa, khususnya pada kegiatan diskusi siswa.

Berdasarkan data hasil wawancara dengan guru menyatakan bahwa prinsip kerja sama Grice baik yang mematuhi maupun melanggar dapat dijadikan sebagai rujukan bahan ajar keterampilan berbicara di SMA.

Memberikan rambu-rambu kepada siswa dalam kegiatan berbicara, khususnya kegiatan diskusi

Rambu-rambu yang dimaksudkan adalah aturan main atau tata tertib pelaksanaan diskusi. Aturan main tersebut dapat berupa perintah dari guru supaya setiap siswa memperhatikan dengan seksama materi atau topik diskusi tersebut. Aturan main ini dapat dijalankan jika setiap siswa menerapkan pematuhan prinsip kerja sama Grice. Hal ini dapat didukung dengan bukti kutipan tuturan siswa dalam proses tanya jawab diskusi berikut ini.

[67]Hesti : "Saya mau tanya, saya baca disini ada testimoni dari penggunanya nicorette. Dia mengatakan bahwa nicorette-nya dia pakai sampai jam 9 malam. Dia yang pakai plester, tetapi setelah nicorette-nya dilepas, dia tetap merasakan keinginan buat merokok lagi. Itu gimana? Berarti nicorette tidak memberikan penyelesaian dong buat perokoknya?" 
[68] Yulita : "Jadi menurut kami gak semuanya itu bisa langsung terlepas dari rokok. Mungkin Cuma beberapa aja yang berhasil." $<\mathrm{MKn}>$

[69] Theo : "Bisa seminggu, dan lainnya."

[70]Yulita : "Jadi kayak belum semuanya berhasil buat berhenti merokok dengan nicorette." $<\mathrm{MKn}>$

Tuturan Yulita berisi kontribusi informasi yang sama yang dibutuhkan

Hesti. Ketika Yulita mematuhi prinsip kerja sama Grice maka proses interaksi dan komunikasi dalam sesi tanya jawab diskusi tersebut pun berjalan lancar. Hesti mampu memahami informasi yang disampaikan Yulita, lalu Hesti meminta konfirmasi lagi. Diskusi pun kembali berjalan lancar. Jadi dapat disimpulkan bahwa prinsip kerja sama Grice dapat dijadikan sebagai rambu-rambu ketika siswa berbicara, sehingga tuturan yang disampaikan siswa tepat sesuai dengan topik diskusi dan mampu mendukung keberlangsungan proses diskusi baik dalam bertanya maupun menjawab.

\section{Memberikan pedoman penilaian bagi guru dalam kegiatan berbicara khususnya} kegiatan diskusi

Pernyataan yang dikatakan Drs. Widodo Eko Rusmanto dan Drs. Sujarwo dalam deskripsi hasil penelitian dapat didukung dengan bukti kutipan tuturan siswa dalam proses tanya jawab diskusi berikut ini.

[348] Fairuz : “Apa tanggapan kalian dari kelompok yang ngomong gini "merokok atau gak merokok tetap aja mati"?"

[352] Novania : “Oke, saya akan menjawab pertanyaan Fairuz, merokok atau gak merokok sama-sama mati. Hidup dan mati seseorang itukan kita gak tahu karena Tuhan yang menentukan kamu mati atau hidup bagaimana dan yang kedua perbedaan ketika kamu mati merokok atau kamu mati tidak merokok adalah bagaimana kamu berusaha menghargai hidup yang diberi sama Tuhan. Mungkin sama-sama mati, tapi yang satu menghargai tubuh yang dikasih oleh Tuhan, yang satunya hidup seenaknya sendiri, seperti itu." $<\mathrm{MKn}>$

Tuturan yang disampaikan oleh Novania tidak melebihi informasi yang dibutuhkan Fairuz. Pertanyaan dari Fairuz membuat Novania harus mengatur pola pikirnya untuk memberikan informasi yang dibutuhkan Fairuz. Hal ini menuntut Novania harus mengetahui fungsinya sebagai mahkluk religious yang harus 
menghargai apa yang sudah diberikan Tuhan kepadanya. Jadi dapat disimpulkan bahwa prinsip kerja sama Grice dapat dijadikan pedoman penilaian bagi guru untuk menilai atau mengukur kemampuan kognitif siswa mengenai topik atau materi diskusi, kemampuan afektif siswa dalam hal sikap ketika menyampaikan pendapat atau berperilaku yang sesuai dengan jawaban yang disampaikannya, dan kemampuan psikomotorik dalam hal kemampuan berbicaranya.

Meningkatkan efektifitas dalam proses pembelajaran keterampilan berbicara khususnya pada kegiatan diskusi

Pertanyaan yang disampaikan oleh Drs. Sujarwo pada deskripsi hasil penelitian dapat dibuktikan melalui kutipan percakapan siswa dalam sesi tanya jawab diskusi telah dilakukan sebagai berikut.

[48] Shinta : "Saya ingin menanggapi pernyataannya Ardan. Saya dari kelompok Precious. Sebelumnya saya mau bertanya. Siapa orang yang menyatakan itu di vlog itu?"

[49] Ardan : "Deddy Corbuzier."

[51] Shinta : "Nah, menurut saya Deddy Corbuzier itu memang orang yang kritis, tapi menurut saya mungkin maksudnya membunuh secara perlahan itu mungkin bisa untuk mengurangi kepadatan penduduk dan sebagainya. Tapi menurutku, negara itu punya cara yang lain untuk mengurangi atau membunuh orang secara tidak langsung, misalnya KB dan lain sebagainya itukan bisa dipakai. Jadi menurutku memang Deddy Corbuzier punya perkataan yang kontroversial dan itu tidak bisa dijadikan alasan atau statement untuk membicarakan hal ini. Terima kasih." $<\mathrm{MKl}>$

Tuturan Shinta tersebut berisi informasi yang benar. Shinta sangat meyakini isi informasi yang disampaikannya. Ia yakin bahwa perkataan Deddy Corbuzier yang kontrovesial dalam $v$ log tersebut tidak bisa dijadikan alasan untuk memberikan solusi mengenai pendapatan negara meningkat karena warganya yang merokok. Pematuhan prinsip kerja sama Grice secara tidak langsung mendorong Shinta supaya mengarahkan pembicaraan diskusi kembali ke topik yang benar dan jelas. Artinya pendapat-pendapat yang sekiranya tidak bisa dibuktikan kebenarannya tidak perlu dibahas dalam sesi tanya jawab diskusi tersebut. Dengan demikian diskusi dapat berjalan dengan lancar dan efektif. Jadi 
dapat disimpulkan bahwa prinsip kerja sama Grice dalam pematuhan maksimmaksimnya dapat meningkatkan efektifitas keterampilan berbicara, khususnya pada kegiatan diskusi siswa.

Peranan pematuhan prinsip kerja sama Grice dalam keterampilan berbicara antara lain membuat diskusi berjalan dengan efektif dan kondusif, siswa antusias dan menjadi fokus pada kegiatan diskusi, waktu diskusi dapat digunakan secara maksimal untuk mengkaji topik yang menarik secara mendalam, dan informasi yang disampaikan tidak menimbulkan kebingungan yang baru, melainkan dapat menjawab rasa keingintahuan siswa secara jelas. Sebaliknya dampak pelanggaran prinsip kerja sama Grice akan membuat diskusi menjadi ramai, kurang terarah, dan tidak efektif dalam waktu. Dampak lainnya adalah siswa tidak fokus pada kegiatan diskusi, melainkan memiliki aktivitas masing-masing yang tidak berkaitan dengan diskusi. Materi atau topik dalam diskusi tidak dapat dikaji secara maksimal.

Pelanggaran prinsip kerja sama Grice tidak sepenuhnya memiliki dampak negatif. Adanya pelanggaran Prinsip kerja sama Grice mampu membuat siswa lebih akrab, misalnya dengan adanya humor atau ada tuturan siswa yang tidak relevan dengan topik diskusi. Hal tersebut dapat membuat siswa lainnya membantu dalam memberi jawaban atau topik yang relevan. Berdasarkan penelitian yang dilakukan oleh Rahayu (2016) yang menyatakan bahwa kajian yang menerapkan prinsip kerja sama Grice mampu memperlihatkan potensi pendidikan karakter dari objek kajian tersebut. Objek penelitian yang dikaji oleh Rahayu (2016) adalah wacana Indonesia Lawak Klub yang didalamnya memiliki tujuh nilai pendidikan karakter yaitu toleransi, mandiri, demokratis, rasa ingin tahu, semangat kebangsaan, cinta tanah air, dan peduli lingkungan. Hal yang sama juga peneliti temukan dalam penerapan prinsip kerja sama Grice pada kegiatan diskusi siswa kelas XI yaitu nilai pendidikan karakter toleransi, rasa ingin tahu, semangat kebangsaan, cinta tanah air, dan peduli lingkungan.

Prinsip kerja sama Grice dapat dijadikan sebagai rujukan bahan ajar keterampilan berbicara, seperti tata tertib diskusi, instrumen penilaian dalam kegiatan diskusi, dan pedoman evaluasi keterampilan berbicara, khususnya 
diskusi. Dengan demikian, keterampilan berbicara siswa akan terus bertambah baik untuk berbicara dengan efektif, benar, relevan, dan ringkas. Prinsip kerja sama Grice ini tidak hanya terbatas pada kegiatan diskusi, tetapi kegiatan berbicara yang sejenis lainnya seperti debat. Hal ini sejalan dengan penelitian yang dilakukan oleh Mulati, (2016) yang menyatakan bahwa adanya pemanfaatan prinsip kerja sama Grice telah menunjukkan bahwa siswa telah mengembangkan keterampilan berbicara. Tuturan antara siswa dan guru telah menunjukkan adanya pemahaman makna yang diterima oleh penutur dan mitra tutur.

\section{SIMPULAN}

Realisasi penggunaan bahasa Indonesia yang mematuhi prinsip kerja sama Grice pada pembelajaran diskusi siswa kelas XI IPA 1 SMAN 4 Surakarta didukung oleh topik diskusi yang sudah dibatasi, yaitu Upaya Menuju Generasi Tanpa Merokok Sebuah Pencegahan dan Penanggulangan. Pematuhan maksim prinsip kerja sama Grice ditemukan pada (1) maksim kuantitas, (2) maksim kualitas, (3) maksim cara, dan (4) maksim relevansi. Pematuhan maksim prinsip kerja sama Grice yang paling dominan muncul pada maksim kuantitas. Hal ini disebabkan oleh kemampuan berbicara siswa yang tinggi dan siswa sangat memahami topik yang sedang dibahas.

Realisasi penggunaan bahasa Indonesia yang melanggar prinsip kerja sama Grice pada kegiatan diskusi siswa kelas XI IPA 1 SMAN 4 Surakarta terjadi karena dipengaruhi oleh faktor internal dan faktor eksternal. Pelanggaran maksim prinsip kerja sama Grice ditemukan pada (1) maksim kuantitas, (2) maksim cara,

(3) maksim relevansi, dan (4) maksim kualitas. Pelanggaran maksim prinsip kerja sama Grice yang paling dominan juga muncul pada maksim kuantitas. Hal ini disebabkan oleh kebutuhan siswa yang sengaja melanggar prinsip kerja sama Grice dengan tujuan memberikan informasi yang sangat jelas, lengkap, dan kemudian diulang dengan tujuan penegasan. Tujuan lainnya adalah dengan maksud humor dan ingin lebih meyakinkan hal yang disampaikan. Pelanggaran prinsip kerja sama Grice yang dilakukan siswa kelas XI IPA 1 SMAN 4 Surakarta dapat terjadi secara sengaja dan tidak sengaja. Siswa sengaja melanggar prinsip 
kerja sama Grice untuk mencapai tujuan tertentu. Lain halnya dengan ketidaksengajaan pelanggaran prinsip kerja sama Grice terjadi karena siswa menyampaikan tuturannya secara langsung tanpa mempertimbangkan atau memikirkannya terlebih dahulu.

Prinsip kerja sama Grice (1) memberikan rambu-rambu kepada siswa dalam kegiatan berbicara, khususnya kegiatan diskusi, (2) memberikan pedoman penilaian bagi guru dalam kegiatan berbicara khususnya kegiatan diskusi, dan (3) meningkatkan efektivitas dalam proses pembelajaran keterampilan berbicara khususnya pada kegiatan diskusi. Adanya hubungan prinsip kerja sama Grice sebagai bahan ajar keterampilan berbicara tersebut dapat meningkatkan keterampilan berbicara siswa SMA, di antaranya dari segi kuantitas yang bagus, kualitas yang bagus, tuturan yang sangat relevan, dan siswa memiliki sikap yang baik ketika berbicara.

\section{DAFTAR PUSTAKA}

Devi, L. N. dan Qomaruddin, M. (2017). Prinsip kerja sama dalam Bahasa Transaksi Jual Beli Online di Tokopedia.com. Jurnal Haluan Sastra Budaya, 1, (1), 86-96.

Ephratt, M. (2012). "We try harder" - Silence and Grice's Cooperative Principle, Maxims and Implicature. Jurnal Language \& Communication, 32, 62-79.

Fajrin, R., Andayani \& Rohmadi, M. (2016). Pelanggaran Prinsip kerja sama dan Pematuhan Prinsip Kesantunan dalam Pembelajaran Bahasa Indonesia di SMK Pelayaran "Akpelni" Semarang. Jurnal S2 Pendidikan Bahasa Indonesia, 1, (1), 100-112.

Handoko, S. F. (2010). Peningkatan Kemampuan Berdiskusi Melalui Penerapan Prinsip kerja sama Grice Pada Siswa Kelas VIII D SMP Negeri 10 Surakarta Tahun Pelajaran 2009/2010. Skripsi Tidak Dipublikasikan. FKIP Universitas Sebelas Maret, Surakarta.

Leech, G. (1993). Prinsip-prinsip Pragmatik. Jakarta: Universitas Indonesia Press.

Mahsun. (2011). Metode Penelitian Bahasa: Tahapan Strategi, Metode, dan Tekniknya. Jakarta: Rajawali Press.

Materka, P. R. (2001). Loka Karya \& Seminar: Perencanaan, Pelaksanaan, Pemanfaatan. Yogyakarta: Kanisius. 
Moleong, L. J. (2007). Metodologi Penelitian Kualitatif(Edisi Revisi). Bandung: PT Remaja Rosdakarya.

Mulati, M. A. T. C., (2016). Pemanfaatan Prinsip kerja sama dalam Komunikasi Diskusi sebagai Aspek Keterampilan Berbicara Mata Pelajaran Bahasa Indonesia Kelas 8 di SMP Muhammadiyah 4 Surakarta. Skripsi Tidak Dipublikasikan. FKIP Muhammadiyah, Surakarta.

Payuyasa, I. N., Sutama, I. M., \& Putrayasa, I. B. (2014). Pelaksanaan Prinsip kerja sama Grice pada Tindak Tutur Guru dan Siswa dalam Pembelajaran Bahasa dan Sastra Indonesia di Kelas XI SMA Negeri 1 Blahbatuh. $e$ Journal Program Pascasarjana Universitas Pendidikan Ganesha, 3.

Rahardi, K. (2005). Pragmatik Kesantunan Imperatif Bahasa Indonesia. Jakarta: Erlangga.

Rahayu, P. (2016). Realisasi Prinsip kerja sama dan Potensi Pendidikan Karakter dalam Wacana "Indonesia Lawak Klub" Trans 7 sebagai Bahan Ajar Bahasa Indonesia di SMA/K. Skripsi Tidak Dipublikasikan. FKIP Muhammadiyah, Surakarta.

Ristiawan, H. (2017). Prinsip kerja sama dalam Berinteraksi di Lingkungan SMPN 11 Kota Jambi. Jurnal Pena, 7, (2), 99-116.

Saddhono, K. \& Slamet, Y. (2014). Pembelajaran Keterampilan Berbahasa Indonesia; Teori dan Aplikasi Edisi 2. Yogyakarta: Graha Ilmu.

Sari, N. W. E. (2013). Pelaksanaan Prinsip kerja sama dalam Percakapan Guru dan Siswa serta Dampaknya terhadap Pembelajaran Bahasa Indonesia di Kelas XI SMAN I Kediri. Jurnal Santiaji Pendidikan, 3, (2), 178-188.

Subroto, D. E. (2007). Pengantar Metode Penelitian Linguistik Struktural. Surakarta: Sebelas Maret University Press.

Sugiyono. (2015). Memahami Penelitian Kualitatif. Yogyakarta : Alfabet.

Wijana, I. D. P \& Rohmadi, M. (2011). Analisis Wacana Pragmatik: Kajian Teori dan Analisis. Surakarta: Yuma Pustaka. 